Association of Historical Studies KORYVANTES,

koryvanteshoplites@gmail.com

Original research article

Received: March $12^{\text {th }} 2013$

Accepted: February $15^{\text {th }} 2014$

\title{
HOPLITES AND ANCIENT GREEK BATTLE FAIR. FROM EXPERIMENTAL ARCHAEOLOGY TO EXPERIENTIAL LEARNING. AN INSIGHT VIEW OF POPULARIZATION METHODS
}

\begin{abstract}
The modern needs on observing and examine the past and the history, demand new and not conventional presentational methods. This article presents with the use of several examples, the ways that Association Koryvantes uses experiential learning for the promotion and the popularization of Archaeology. Innovative ways of communication, which enable archaeology outcomes to be accepted by the general public with a maximum effectiveness.
\end{abstract}

Keywords: experiential learning, interactive participation, Association Koryvantes, popularization, experimental archaeology.

\section{INTRODUCTION}

The development in the archaeological world over the past several decades has been undoubtful and multidimentional. The several routes in which archaeology has been evolved in combination with other sciences has given us new dimensions on the understanding of an archaeological discovery. The modern needs on observing and examine the past and the history, demand new and not conventional presentational methods. Methods that have to involve the receiver and make him part of what is going to be presented.

Especially children, as the most related to this, have to be in the centre of those presentational methods and techniques. Experiential learning and interactive participations can help children to learn

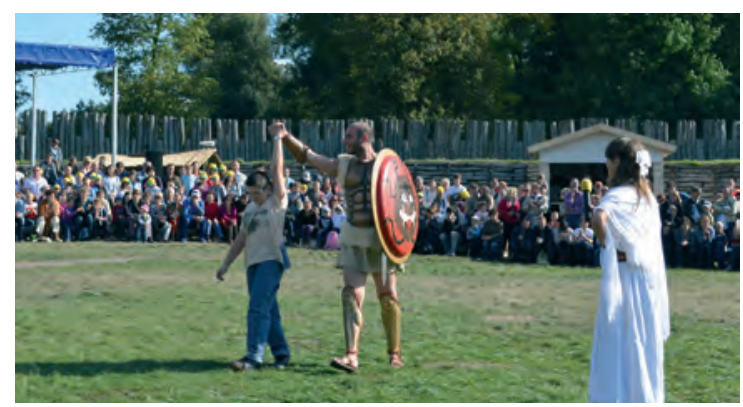

Fig. 1 Kinaesthetic Activities with children in Biskupin Archaeological Festival, 2011 (photo Association of Historical Studies Koryvantes)

by exploring, experiencing, and transact with the world around them. This form of education is not conventional. Children are allowed to learn naturally, on their own terms. Experiential education can occur via acts like creative workshops, playing, pretend playing, imaginative participations. 


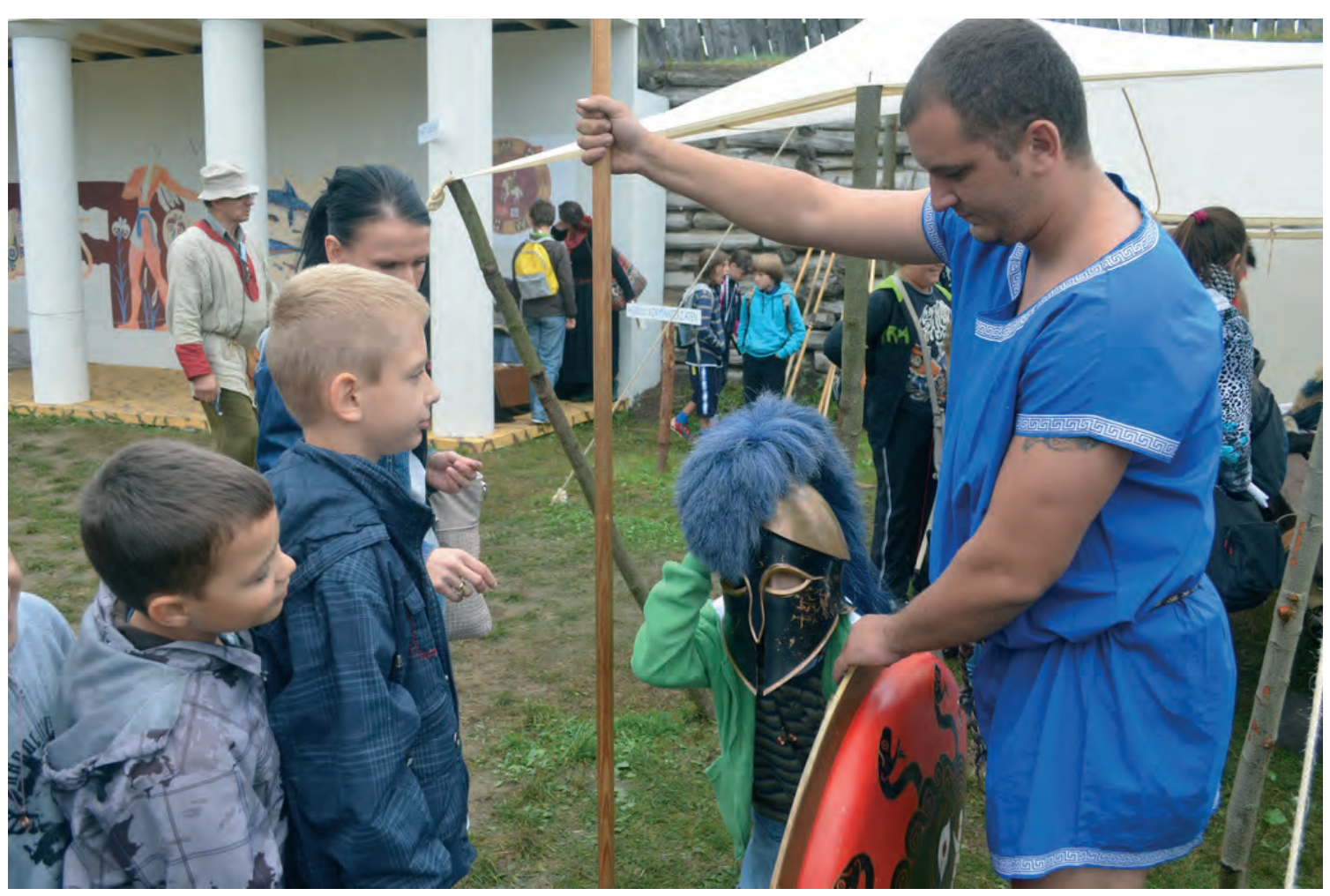

Fig. 2 Interactive workshops with children in Biskupin Archaeological Festival, 2011 (photo Association of Historical Studies Koryvantes)

One to one transaction enhances physical learning, a language that includes kinaesthetic activities, natural to most children (Griss 1998).

Neuroscientists also confirm that learners who have been offered several modes of representation generate more brain activity, because they try to correlate these stimuli. (Watson, 2005). Thus, stimulation of multiple sensory experiences (speech, actions, pictures, symbols) can offer deeper understanding of a new concept. This position is also reflected in Howard-Jones' (2011) findings that simple learning games help students recall easily newly learned information. These results give rise to the elusive theory of 'edutainment' (experiences that combine education with the entertainment of games).

Furthermore, recent neuroscientific research adds new perspectives to better understand the role that kinaesthetic activities and movement plays in learning (Jensen, 2005; Watson, 2005). Jensen (2005) stresses the importance of integrating movement activities into everyday learning. According to him, brain-compatible learning means that educators should teach lessons along with movement, drama and the arts. Finally, a Johns Hopkins University neuroeducation research group found that intense training in visual arts, music and dance was associated with better geometric sensitivity performance (Johns Hopkins University NeuroEducation Initiative, 2009). These promising results can help educators further their understanding of the ways their students learn and can provoke thinking with regard to broader educational issues.

\section{EXPERIENTIAL LEARNING}

The Association of Historical Studies 'Koryvantes' deals with experimental archaeology, historical reconstruction and reenacting. It concentrates on the study of ancient Greek warfare through experimental archaeology techniques, covering a time range from the $15^{\text {th }}$ to the $3^{\text {rd }}$ century BC. Until now we have reconstructed successfully various types of warrior accoutrement 


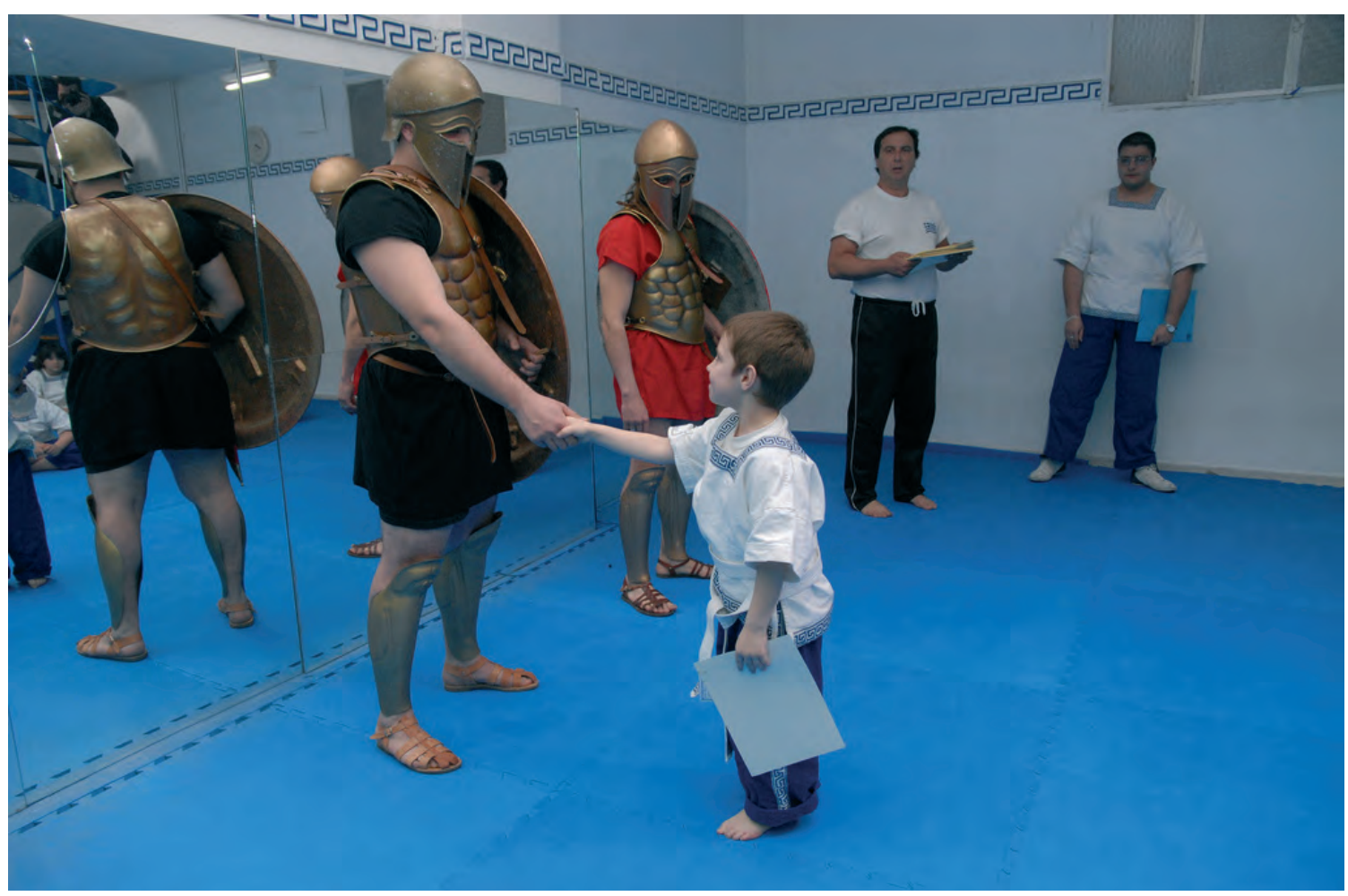

Fig. 3 Interactive workshops with children in a Greek Private School, 2008 (photo Association of Historical Studies Koryvantes)

from the $10^{\text {th }}$ to the $5^{\text {th }}$ century BC. The Koryvantes Association has been active officially from 2009, as a non-profit, living history association. The Association counts more than 45 active members in Greece and abroad, amongst them writers, researchers, reenactors and history enthusiasts. During these four years of activity, the Association has managed to be productive on many levels related to historical research issues, e.g. participation in experimental archaeology projects, publications of experimental results, participation in numerous educative public events and international documentaries (Bakas 2012).

Working with the scope of research and reconstruction of ancient weapons and armors covering most of the Greek Military History from Bronze Age down to the appearance of firearms, the Association of Historical Studies Koryvantes is in position to comprehend the unrealistic nature of reconstructions undertaken under a set of lax approaches and image-copying approximations and it stresses the need to introduce methodologies and techniques of Experimental Archaeolo- gy. This need rises in all ages from Mycenaean to Late Byzantine - especially the latter for which we do not have any real finding relying solely on few artistic depictions.

Without any doubt experimental archeology has indisputable advantages as an interactive medium between performers and the general public. Living history and a revival of the past in realistic fashion can be achieved by a natural fusion of protagonists and spectators (Bakas 2010). Our club had the opportunity to implement experimental archeology with interactive applications during several events and workshops, combining the archeological reconstructions with the live communication with the audience. Generic activation of the human senses (touch, hearing, vision, smell) and the simultaneous participation of a receiving audience during the presentation guarantee acceptance of the results of experimental archaeology (Bakas 2012). In this context, our Association participates regularly in various public activities, such as demonstrations and lectures for children and students, public presentations at 


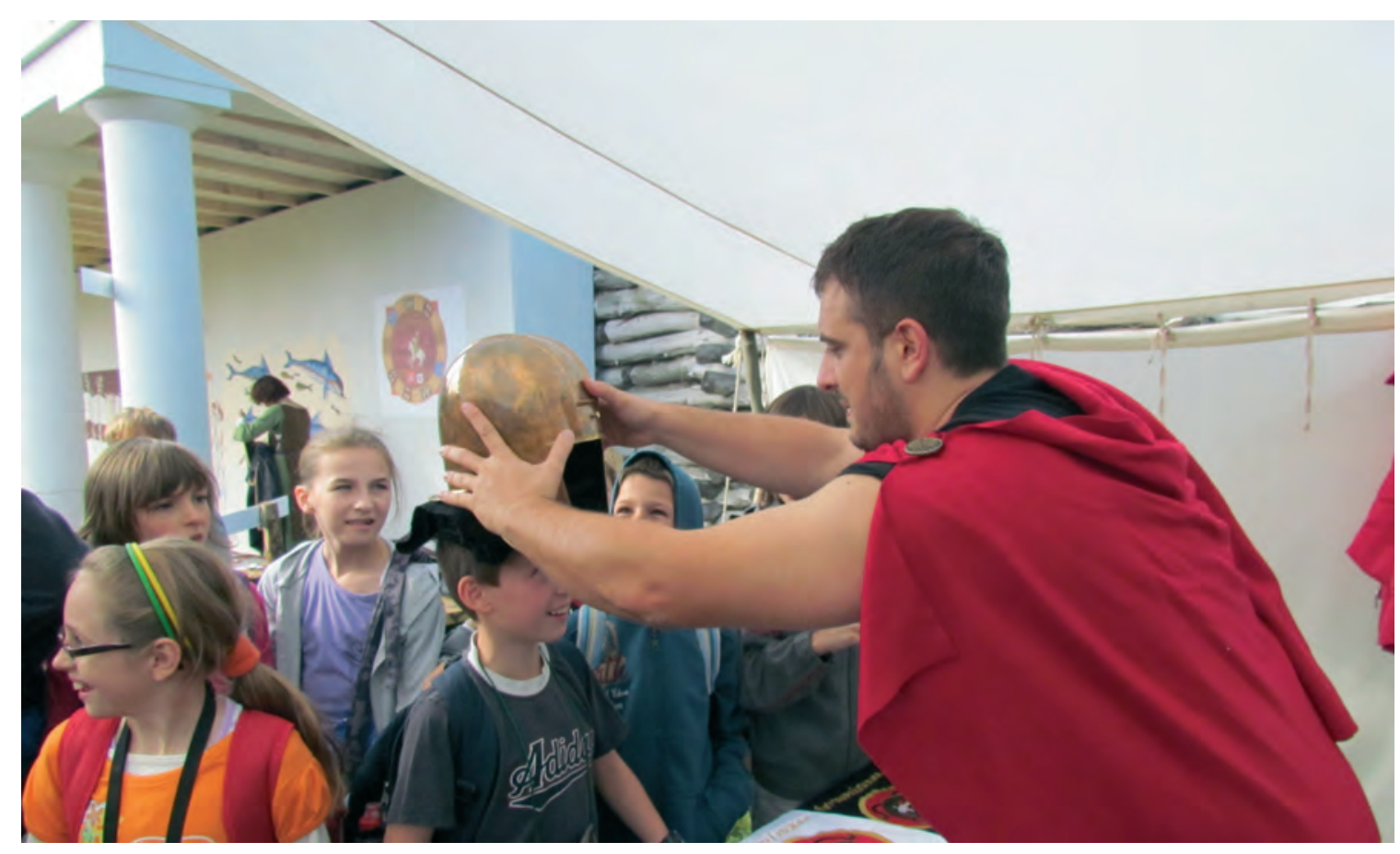

Fig. 4 Transaction with children in Biskupin Archaeological Festival, 2011 (photo Association of Historical Studies Koryvantes)

cultural events and public lectures about Ancient Greek martial arts. These aspects are easy to find in modern interactive marketing and have been introduced at many archaeological parks (Yorke and Uzi 2004, 10-20).

Our participation on the Biskupin Archaeological Festival in Poland (17-25 September 2011) gave us a critical opportunity to deploy various popularization methods under the guidance and strategic plan of educational supervisors. The results of experimental archeology, such as a technical movement, a hoplite phalanx drill and phalanx formation, were combined harmoniously and amusingly with the participation of small children during the event. The audience and mostly the children were the aiming center of our presentations. We used several means trying to convince the children that the heavily armored hoplites were not some fearsome monsters but somehow «heroes» who were willing to be approached and could be friends with them.

One interesting workshop was the «Hoplitodromia» race, a race used to be held by the ancient Greek warriors and athletes carrying only a shield. Each time 5 randomly selected children were urged to participate on this race, in front of the hundreds of the audience. The final price for the winner would be a Koryvantes t-shirt and an olive wreath. While the whole history of the Hoplitodromia race was described by a specialist through a microphone, the children had the opportunity to realise the importance and the cultural meaning of this representation and participation.

The end result of the workshop was surprisingly successful and satisfactory. The collaboration between the hoplites and the children, and the two-way interactive transaction gave the children the opportunity to express themselves in the most effective way. When an interactive lesson of experimental archeology is being linked to kinesthetic experiences, the result is that the children gain a deeper understanding of the content than an isolated course. A flexible approach to History and Archaeology education is necessary to encourage this kind of learning. The experience we obtained doing this interactive course helped us cultivate a more holistic view on this subject and gave us more ideas for our upcoming public presentations.

Another interesting workshop was during our participation in Gallo-Romain Internation- 


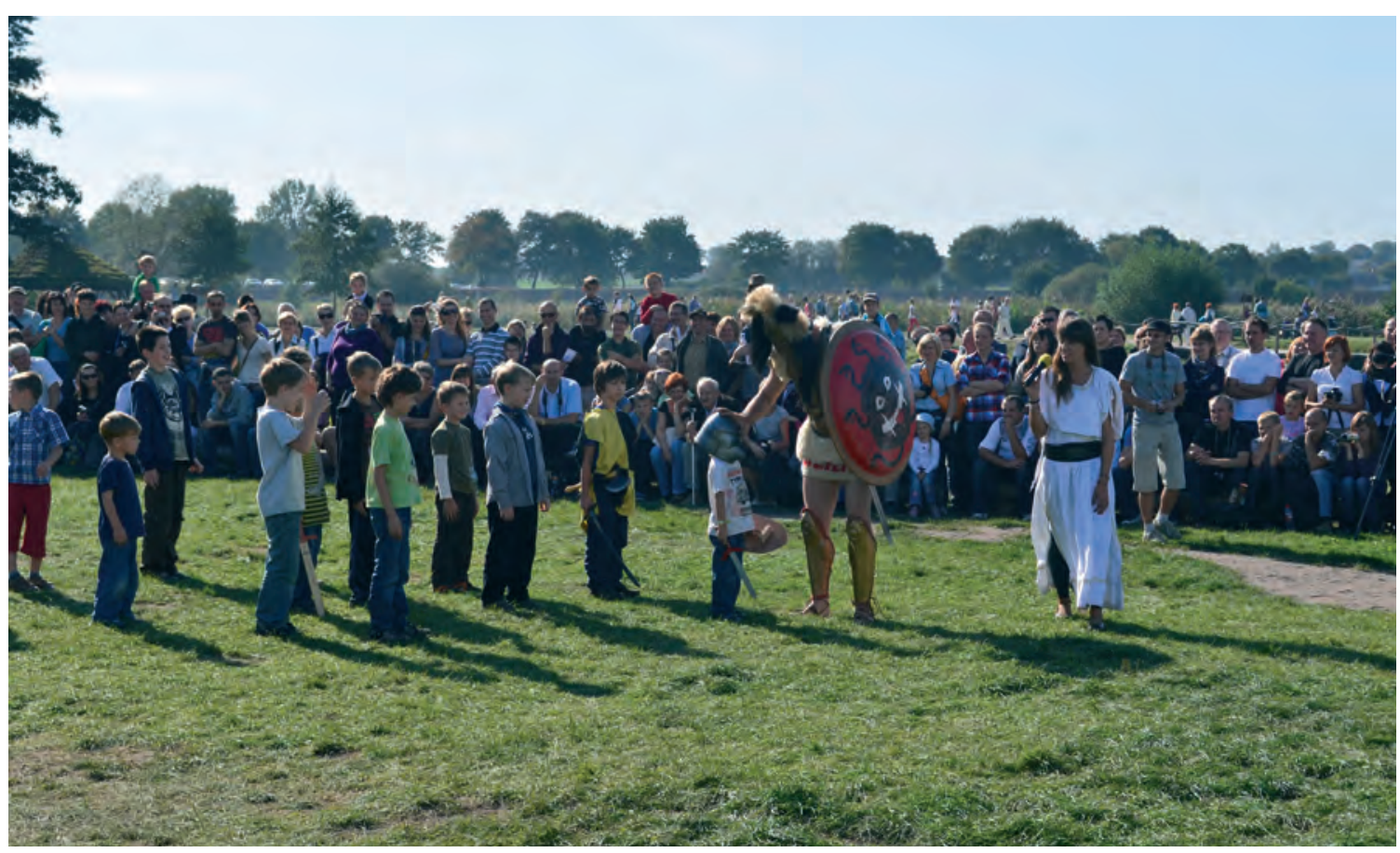

Fig. 5 Kinaesthetic Activities with children in Biskupin Archaeological Festival, 2011 (photo Association of Historical Studies Koryvantes)

al Archaeological Festival in France (June 2-3 2012). Our participation was under the directions of educational specialists who guide us on new popularization techniques and activities. Along with individuals visitors we had the opportunity to welcome primary schools with their teachers. During this, while on our exhibition tent, we urged the children to try to touch and wear our armour (always in safety mode). We gave emphasis on creativity, imagination and collaboration. We then urged them to talk between each other and try to make stories of imaginary ancient warriors and heroes. This exercise gave the students enough space to move, play and create their own piece of artistic work and encouraged conversations and working in groups in order to support their historical and social learning. It was impressive how aesthetically valuable, the choreographies they created were. The freedom to experiment and create moves and scenarios was regarded as fun, and also the sheer enjoyment of the physical movement opposed to 'bookish' learning. This kinaesthetic experience was appreciated by all the participant children.

Nevertheless, we were also aware of the fact that students' creativity might be affected by our presence, but surprisingly nothing happened. A meaningful interpretation of the results regarding the relationship between kinaesthetic learning and students with specific learning needs in history is needful. It is important to remember that the supervising teachers noted that during this workshop the students with 'specific learning needs in history' and 'behaviourally challenging children' who are 'kinaesthetic learners', were very active, participative and 'really enjoyed it'. According to the teachers this workshop gave them an opportunity to 'have a different way of learning', feel included - as they 'did as much as anyone else' - and, above all, 'helped their learning on history and archaeology going further.

\section{CONCLUSION}

Thinking about traditional archaeology and modern educational methods as two diverse and non-overlapping fields is at least erroneous and should stimulate the debate on the importance of a holistic educational system, in which all areas of the curriculum should be linked and be opened to new options. Resolution of this problem would 
have catalytic effects in education as it has the prospect of breaking through the current curriculum structure, the teaching guidelines and the educational system in general.

\section{ACKNOWLEDGMENTS}

I would like to thank Mr Georgios Kanakaris and Mr Nikolaos Kleisiaris, members of Association Koryvantes for their valuable contribution on this research.

\section{BIBLIOGRAPHY}

Bakas, S. 2012

Amateurs and archaeology. Experimental method or madness? How do we share it all? Archaeological Heritage: Methods of Education and Popularization, Chowaniec-Więckowski (Eds), Oxford: 9-13.

Bakas, S. 2010

World Traditional Archery: History and Present Situation of Preservation, in Proceedings of WTAF International Academic Seminar 2010, 150-152. Cheonan City: The National Association of Archery for All Publishing.

Griss, S. 1998

Minds in Motion, Heinemann Publishing, Portsmouth, $N H$ : 1-14.

\section{Howard-Jones, P. 2011}

Towards a Science of Learning Games, Mind, Brain and Education, 5(1): 33-41.

Jensen, E. 2005

Teaching with the Brain in Mind (2nd Ed.), Alexandria, VA: Association for Supervision and Curriculum Development.

Johns Hopkins University NeuroEducation Initiative, 2009

NeuroEducation: Learning, arts, and the brain: Findings and challenges for educators and re- searchers from the 2009 Johns Hopkins University Summit. Baltimore: Johns Hopkins University.

Watson, A. 2005

Dance and mathematics: Engaging senses in learning. Australian Senior Mathematics Journal, 19(1):16-23.

Yorkem, R. and Uzi, A. 2004

Archaeology and the Consumption of the Past: Oxford: Altamira Press.

\section{REZIME}

\section{HOPLITI I ANTIČKO GRČKO BORILAŠTVO. OD EKSPERIMENTALNE ARHEOLOGIJE DO EMPIRIJSKOG UČENJA. RAZMATRANJE SUŠTINE METODA POPULARIZACIJE}

Ključne reči: empirijsko učenje, interaktivno učešće, asocijacija Koryvantes, popularizacija, eksperimentalna arheologija.

Savremeno doba zahteva nove i nekonvencionalne metode prezentacije kojima se tumače rezultati dobijeni proučavanjem prošlosti. U ovom radu je prikazana upotreba nekoliko novih metoda, koje društvo Korivantes koristi u eksperimentalnom učenju i promociji i popularizaciji arheologije. To su novi, inovativni načini komunikacije, koji omogućavaju razumevanje arheologije u široj javnosti u najvećoj mogućoj meri. 